\title{
Rising trends towards the development of oral herbal male contraceptive: an insight review
}

\author{
Surender Verma* and Akash Yadav ${ }^{*}$
}

\begin{abstract}
Background: Acknowledging population control to be an essential step for global health promotes wide research study in the area of male contraception. Although there are a great number of synthetic contraceptives available in the market, they have plenty of adverse effects. Different potential strategies for male contraception were investigated over a long period time consisting of hormonal, chemical, and immunological interventions, although these methods showed good antifertility results with low failure rates relative to condoms.

Main text: This review is based upon the concept of herbal contraceptives which are an effective method for controlling the fertility of animals and humans. This review has highlighted herbal medicinal plants and plant extracts which have been reported to possess significant antifertility action in males. The review considers those plants which are used traditionally for their spermicidal and antispermatogenic activities and imbalance essential hormones for fertility purposes and plants with reported animal studies as well as some with human studies for antifertility effect along with their doses, chemical constituents, and mechanism of action of the antifertility effect of the plants. This review also explains the phases of sperm formation, hormone production, and the mechanism of male contraceptives.

Conclusion: As far as the relevance of the current review is discussed, it might be quite useful in generating monographs on plants and recommendations on their use. A lot of the plant species listed here might appear promising as effective alternative oral fertility-regulating agents in males. Therefore, significant research into the chemical and biological properties of such less-explored plants is still needed to determine their contraceptive efficacy and also to possibly define their toxic effects so that these ingredients can be utilized with confidence to regulate male fertility. The new inventions in this field are necessary to concentrate on modern, more potent drugs with less harmful content and that are self-administrable, less costly, and entirely reversible.
\end{abstract}

Keywords: Antifertility, Family planning, Herbal contraceptives, Herbs, Mechanisms, Oral male contraceptives, Overpopulation

\section{Background}

Today, overpopulation is a matter of extreme concern for developed nations along with developing countries $[1,2]$. In the year 2011, the world population was estimated at 6,928,198, 253 and increasing rapidly at a rate of 83 million citizens per year [3]. Among developing countries, India is densely populated and it is estimated that it will reach about 9.2 billion by

*Correspondence: svpharma.kuk@gmail.com; akashyadav17494@gmail.com Institute of Pharmaceutical Sciences, Kurukshetra University, Kurukshetra, Haryana 136119, India

\section{Springer Open}

the year $2050[1,2]$. The year 2012 witnessed population figures reaching 1,210,193,422 [1] with an increment of 18 million to the total population every year [2]. According to India's population in 2019, figures are 1,372,717,495 [4]. Increasing population leads to an increase in the demand for resources like water and food, starvation, malnutrition, and consumption of natural resources. Since natural resources are limited, control of the increasing population is a mandatory step [5]. Family planning is an easy and important tool for controlling population burden [6]. On other hand, in

(c) The Author(s). 2020 Open Access This article is licensed under a Creative Commons Attribution 4.0 International License, which permits use, sharing, adaptation, distribution and reproduction in any medium or format, as long as you give appropriate credit to the original author(s) and the source, provide a link to the Creative Commons licence, and indicate if changes were made. The images or other third party material in this article are included in the article's Creative Commons licence, unless indicated otherwise in a credit line to the material. If material is not included in the article's Creative Commons licence and your intended use is not permitted by statutory regulation or exceeds the permitted use, you will need to obtain permission directly from the copyright holder. To view a copy of this licence, visit http://creativecommons.org/licenses/by/4.0/. 
the USA, the unwanted pregnancy rate is approximately $45 \%$ with the help of the various contraceptive options provided to women [7]. Although female contraceptives are much effective in preventing unplanned pregnancy, giving high yielding results, it cannot be used by a greater proportion of sex due to their profuse adverse effects [8].

Talking about extreme measures, the World health Organization has initiated a population control program that includes trials linked to traditional medical activities [2]. Many methods for induction of infertility are implemented over a long period that involves biochemical, biological, and immunological pathways [9] with the least impact but minimal inadequacy [5]. During ancient times, the human reproduction system was not fully established. Hence, the progress in research could not be put into practice due to unclear mechanisms related to human hormones [10].

\section{Main text}

\section{Methods and materials}

The present study has been geared up with wide-ranging facts of curative plants inhabiting all over the world concerning their accepted tradition by countless ethnic groups for fertility regulation in males. To date, no examination has analyzed the dose, constituents of elements, and mechanism of action of the antifertility effect of plants.

So, information concerning this article has been systematically gathered from the sources of scientific literature, including PubMed, Google Scholar, Science Direct, and Scopus. Simply applicable studies available in the English language were considered. The botanical and English names are considered after validation from available text and database. The criteria followed for the choice of information in this evaluation deliberate folk plant:

1. Found in Ancient Indian medicines

2. With recorded animal studies for effects on infertility as well as those with human studies of antifertility effect

Plants, their parts, or their extracts traditionally used for spermicidal and antispermatogenic activities and those that imbalance essential hormones for fertility purposes have been considered as antifertility agents. Furthermore, compounds isolated from plants with attributed potential for fertility regulation are also classified into 6 categories:

1. Phytoconstituents with spermicidal activity

2. Phytoconstituents with antispermatogenic activity

3. Phytoconstituents acts through Sertoli cells

4. Phytoconstituents acts through Leydig cells
5. Phytoconstituents with antimotility activity

6. Phytoconstituents acts by unbalancing hormones

The following keywords were used to search the literature in the data sources: oral male contraceptives, herbal contraceptives, antifertility, and male contraception.

\section{The need of male contraceptives-a boon for society!!!}

Acknowledging population control to be an essential step for global health promotes an opportunity for a large-scale research study in the field of male contraceptives [11]. Male contraceptives originated with the use of a condom in ancient times in Imperial Rome. Researches on male contraception initiated with the sole objective of taking easy targets to the male reproductive system by stopping either the sperm or the testis to function [10]. Although there are a great number of synthetic contraceptives available in the market, they have plenty of adverse effects [5].

Moreover, there is a rise in the need for male contraceptives to avoid unwanted pregnancies because not many men wish to take responsibility for family planning [8]. Also due to the adverse effects of synthetic male contraceptives, the quest for a modern, more effective, more reliable, and less expansive approach is the priority as well as objectives for the pharmaceutical and medical sciences not to forget an unusual self-administration and long-lasting effect of male contraceptives [9]. The new inventions in this field often concentrate on modern, more potent drugs with less harmful content and that are self-administrable, less costly, and entirely reversible [12].

\section{Why not herbals???}

Since ancient times, plants are always regarded as a potent source of nourishment that we require for staying healthy along with their valuable components commonly used for food and nutrition, beverages, cosmetics, dyes, medicines, etc. Herbs are excellent examples of being one of the richest sources of nutrients that aim at protecting and restoring a healthy life [13]. As specified by the World Health Organization (WHO) statistics, almost $65-80 \%$ of the world's population relies on plant species and their health care products due to the lack of modern facilities and poor conditions. There is a total of 422,000 plant species that have been recorded all over the world, out of which 20,000 species are acclaimed as wild edible species and less than 20,000 of the same community is consumed as a food supplement for $90 \%$ of people around the world, contributing to almost $25 \%$ of drug formulations from plants or their extracts [14]. The herbal preparations have been used as an oral tradition. It is becoming more popular and useful in modern times as demand for natural remedies/medicines is increasing 
every day because of the belief of people that they do not have any adverse effects, a boon in disguise [15]. Continuing the traditional system of medicines, more than 35,000 plant species are being used worldwide for medicinal purposes. Following which, more than $80 \%$ of the world population is turning to herbal preparations that contain plant extracts for primary health care [2].

Herbal contraceptives are plant-based contraceptives which are effective methods for controlling the fertility of animals and humans [16]. The chemical constituents of plants such as flavonoids, terpenes, tannins, quinines, diterpenoids, and lactones are apprehended to possess antifertility action through a different mechanism [17]. Different potential mechanisms for male contraception have been studied over a long period of time consisting of hormonal, chemical, and immunological strategies [2, $18]$ though these methods have shown better results of antifertility effects with minimum failure rates than condoms.

In recent years, plants have been reported to be used in the regulation of male fertility because of the better compatibility with the human body, better cultural acceptability, and lesser adverse effects giving it an upper hand [19]. As a result, herbal products attract scientists as a primary source of naturally occurring antifertility agents due to little or negligible adverse signs [17]. For instance, in India, several herbal plants have been reported to have antifertility effects that act through the mechanism by suppression of spermatogenesis or by prevention of implantation [20].
Phases for sperm formation

Testicular carries out two primary goals:

1. Testosterone production

2. Spermatogenesis (origin of haploid germ cells) [8] (Fig. 1)

Flow sheet for production of hormones [21] (Fig. 2) Pituitary gonadotrophins regulate the functions of the testicles, with luteinizing hormones ( $\mathrm{LH}$ ) acting on the testosterone and producing interstitial cells and the folliclestimulating hormone (FSH) affecting the cells of the seminiferous tubules. Including the seminiferous epithelium's structural elements, the movement of nutritional growth factor to the haploid germ cells with a near junction in the epithelium for consecutive cells is known as the "bloodtestis barrier." Well-performing Sertoli cells supply sufficient mitogens, distinct factors, and energy sources to the growing germ cell, as well as shielding them from the host's own immune system from harmful agents. The number and function of the present Sertoli cells define the spermatogenesis rate and quality [22].

\section{Male contraceptives might work as follows:}

1. Suppress sperm production by antispermatogenic

2. Prevention of maturation of sperm

3. Prevention of the flow of sperm through vas deferens

4. Prevention of deposition of the sperm [1]

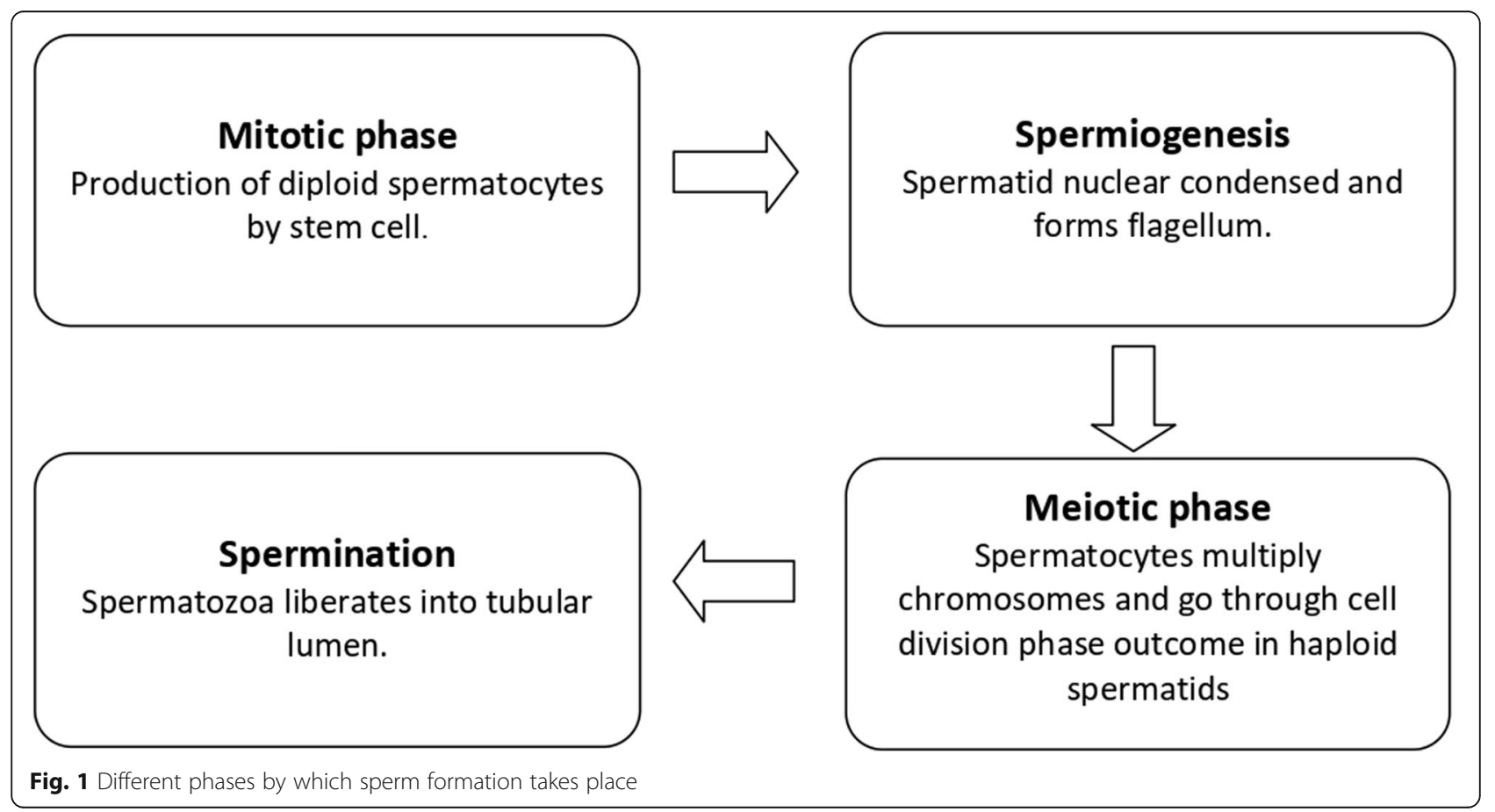




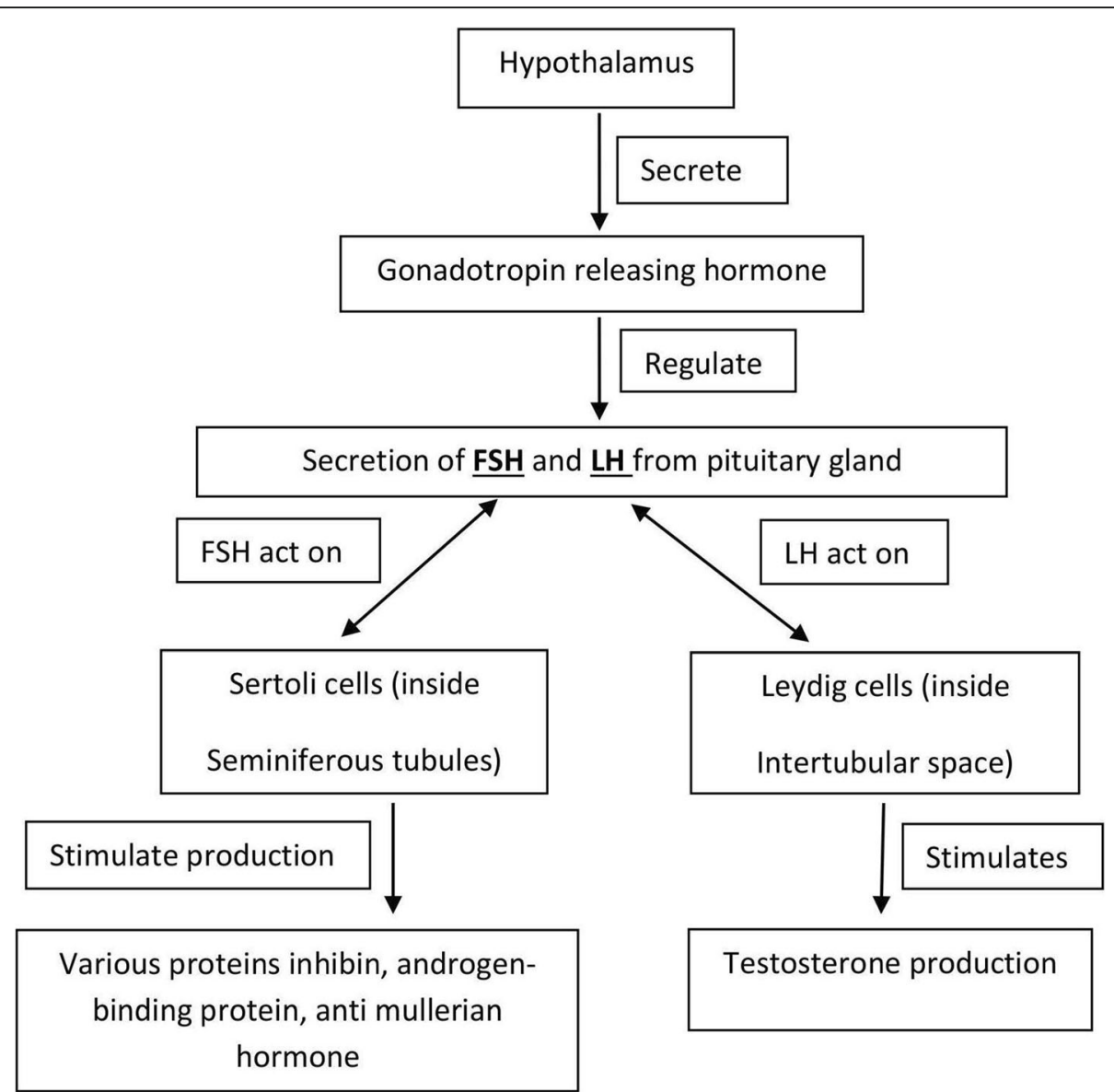

Fig. 2 Release and production of different hormones from glands

\section{Phytoconstituents with spermicidal agents}

Ideal spermicidal characteristics include the following: would rapidly and irreversibly achieve sperm immobilization, are not harmful to the vaginal and penile mucosa, do not have any side effects on the growing fetus that are free from long-term topical and systemic toxicity, and should not be ingested systemically [23]. A typical lipid bilayer consisting of outer, intra, and transmembrane proteins is a key component of the plasma membrane of sperms. This lipid bilayer associate with saponin molecules, impacting cell membrane glycoproteins and altering ionic movement across the membrane, resulting in many plants (Phytolacca dodecadra, Calendula officinalis, and Acacia caesia) differing [24]. Sperm immobilization can be caused by the acid $\mathrm{pH}$ of lemon juice through the denaturation of ATPase dyein [23].

\section{Phytoconstituents with antispermatogenic activity}

The spermatogenesis process involves a complex process:

1. Spermatocytogenesis
2. Spermatidogenesis

3. Spermiogenesis

A diploid spermatogonium undergoes mitotic division in the process of spermatocytogenesis and develops two diploids known as primary spermatocytes. Every primary spermatocyte divides into two haploid secondary spermatocytes by meiosis. Spermiogenesis is the process of spermatid differentiation into mature sperm. It indicates interference in the steroidogenesis when the cholesterol level rises and sudanophilic lipid accumulates [25].

\section{Phytoconstituents acts through Sertoli cells}

Sertoli cells are columnar with oval or pear nuclei and thin mitochondria; at the base of their cytoplasm, they have lipofuscin and lipid droplets. The main feature of Sertoli cell structural support for germ cell development is the blood test barrier, which is situated between neighboring Sertoli cells in close junctions. Sertoli cells play an important part in the process of spermatogenesis and adult life as a whole. The plant extracts kill the viability and work of Sertoli cells and have various effects 
on spermatogenesis, such as reducing the nuclear and cytoplasmic volume and vacuolizing Sertoli cells [26].

\section{Phytoconstituents acts through Leydig cells}

Leydig cells are polyhedral with a large prominent nucleus, an eosinophilic cytoplasm, and various vesicles packed with lipids. The hormone-releasing gonadotropin, secreted and synthesized by the hypothalamus, produces and releases LH and FSH from the pituitary gland. LH induces the production of testosterone in the testis Leydig cells [27].

\section{Phytoconstituents with antimotility activity}

The sperm passes through three sections of the caput, corpus, and cauda epididymis that are important for sperm maturation [28]. Therefore, the production and secretion of proteins through the epididymis and the completion of various morphological, biochemical, and motile properties during the transformation from epididymis are important for the spermatozoa's full capacity to fertilize [29].

\section{Phytoconstituents acts by unbalancing hormone}

Hypothalamus, pituitary gland, and testis secrete the various hormones which regulate spermatogenesis [30]. The Leydig cells synthesize and secrete the major male sex hormone testosterone under the influence of pituitary gonadotropin luteinizing hormone (LH). Several plant products are considered to contain enzymes that are used in androgen synthesis [31]. Quassia Amara's blunt methanol extract shows lower levels of testosterone, LH, and hormone-stimulating follicles (Fig. 3) (Table 1)

Epidemiological studies have shown that the use of combination oral contraceptives increases the possibility of brain thrombosis; enhances the serum triglyceride, high-density lipoprotein (HDL), and cholesterol levels; and also increases family mortality related to cardiovascular diseases as well as malignant tumors in any organ, low resistance to glucose or insulin, diarrhea, abdominal pain, fatigue, hypertension, and menstrual shifts [2].

Patents available are shown Table 2.

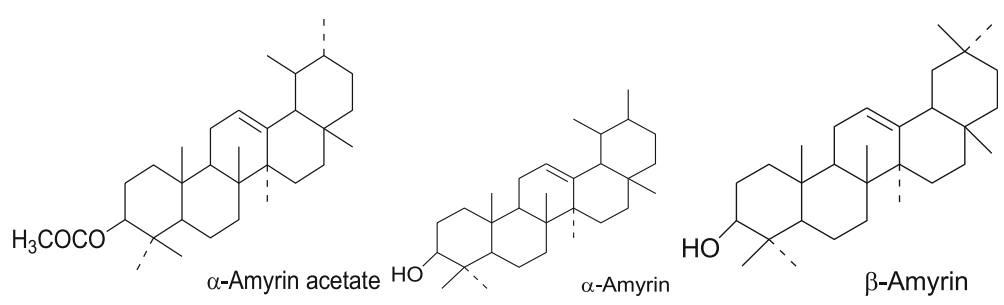

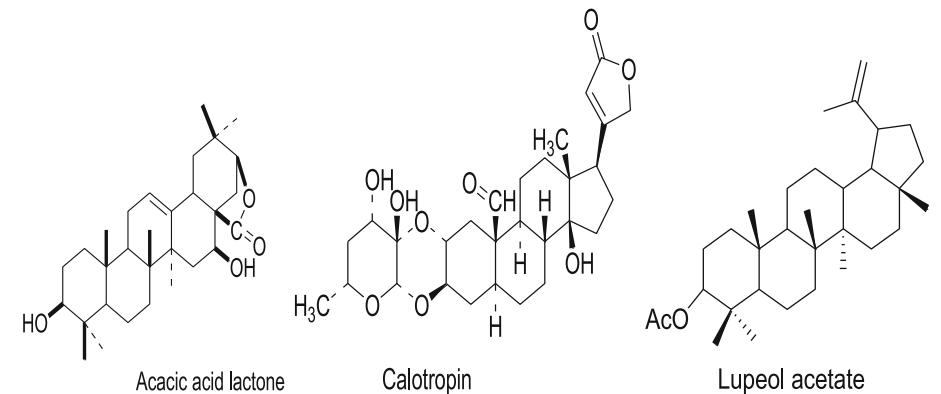

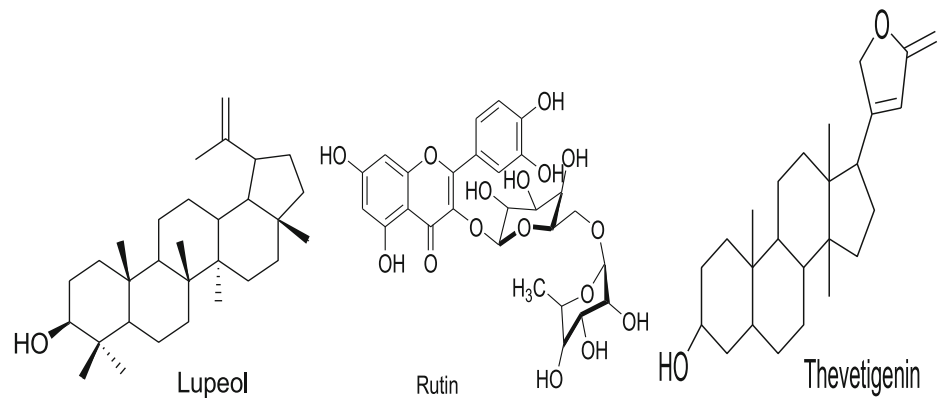

Fig. 3 Isolated compounds from plants having antifertility activity 


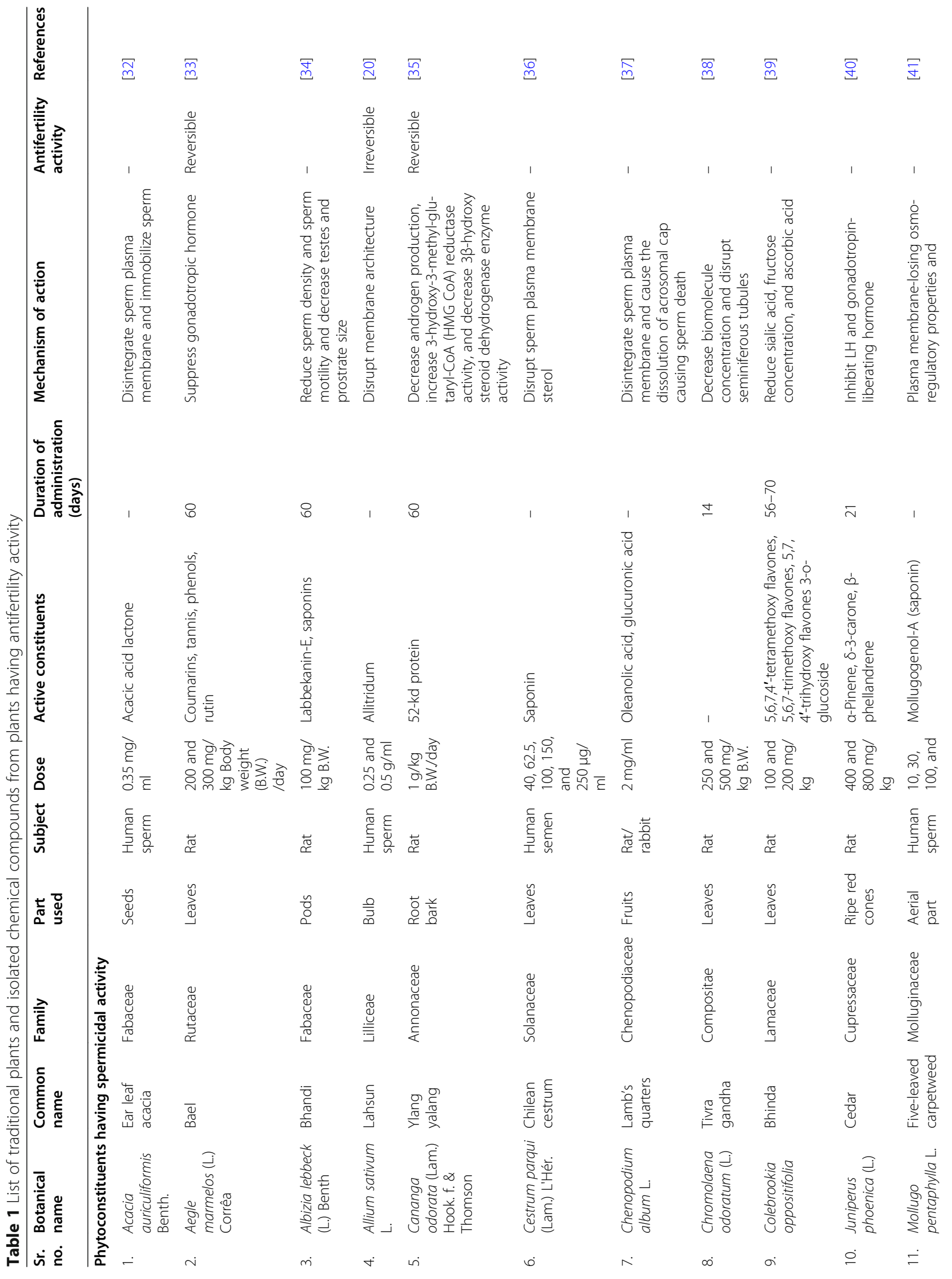




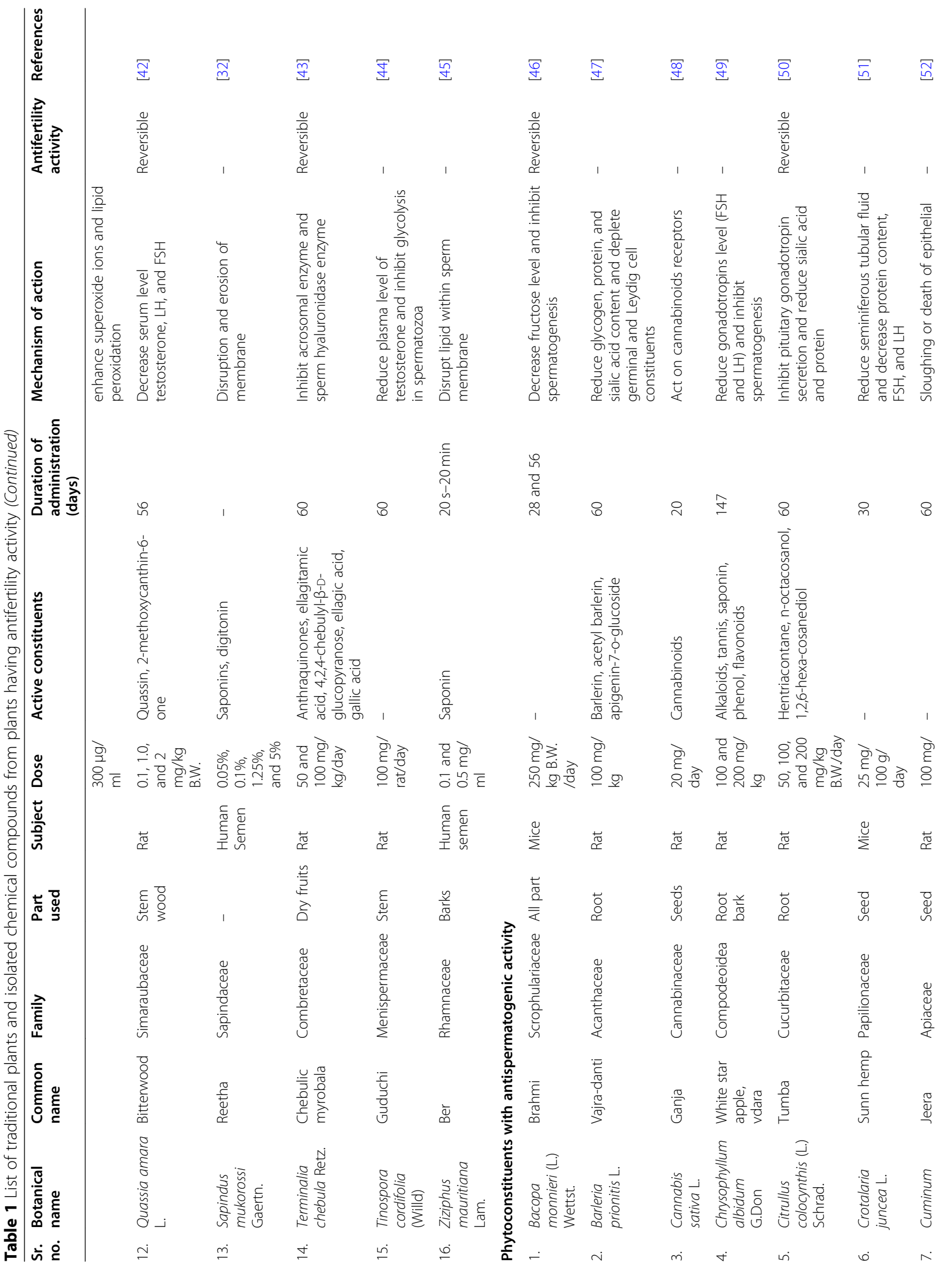




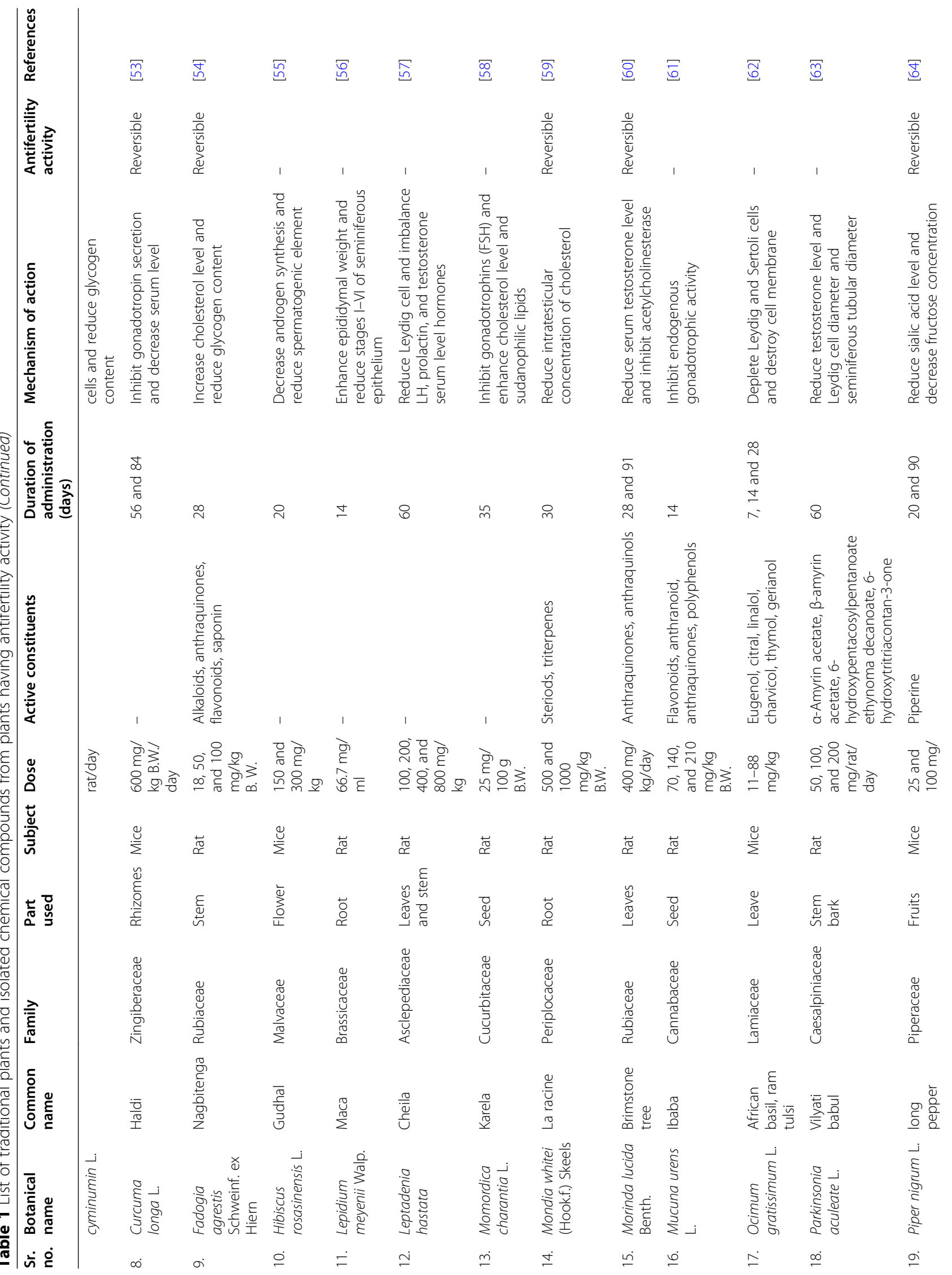




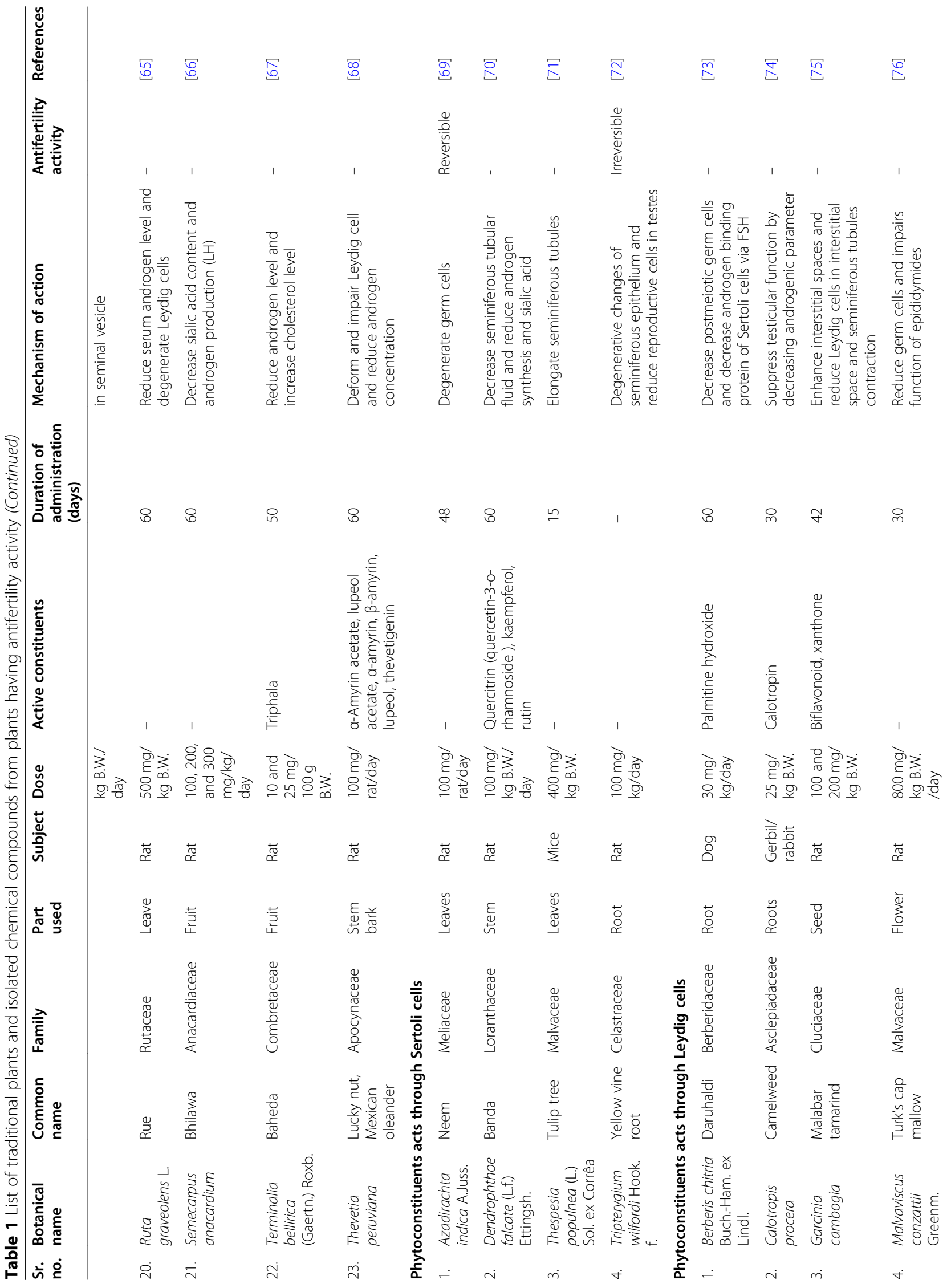




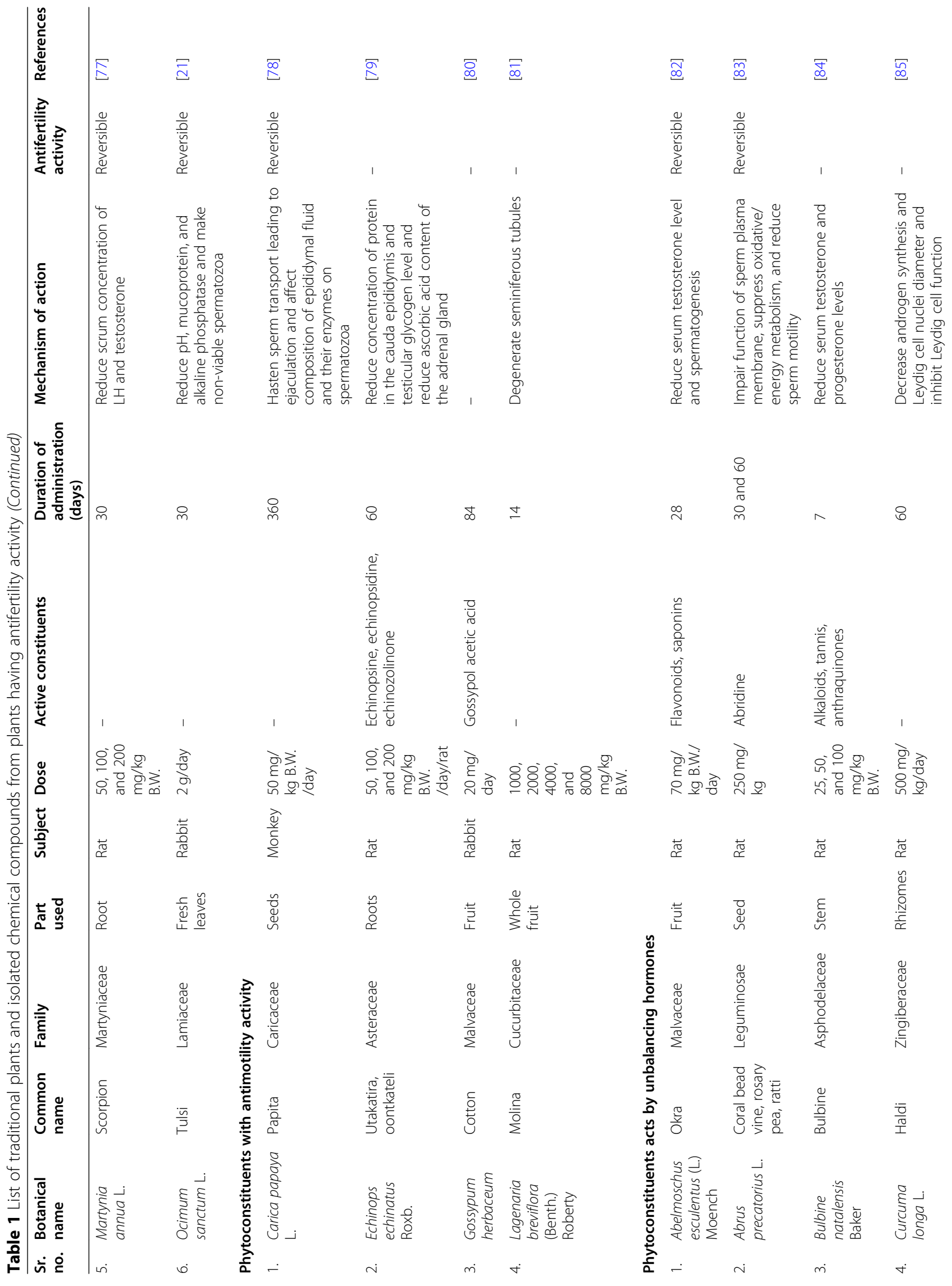




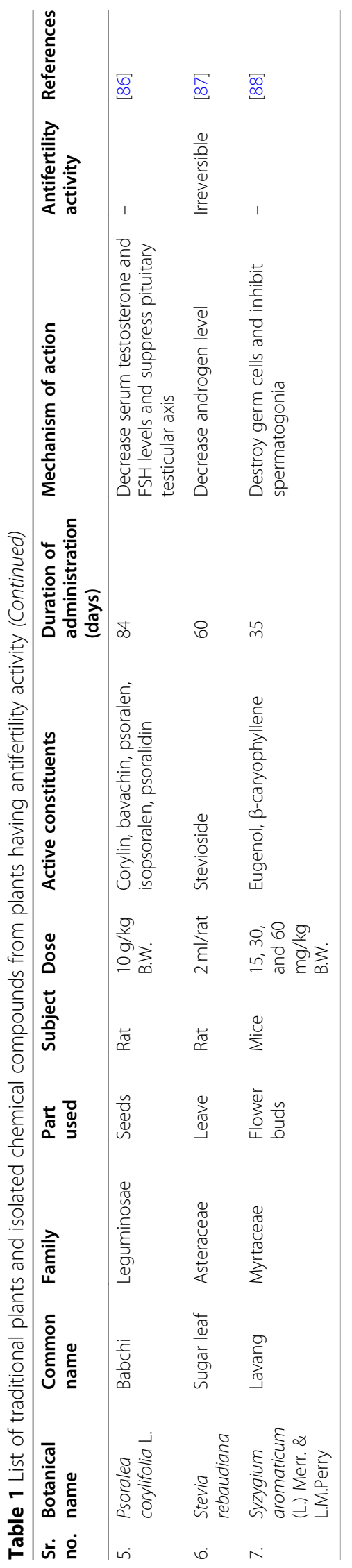




\section{Conclusion}

Different potential strategies for male contraception were investigated over a long period time consisting of hormonal, chemical, and immunological interventions, although these methods showed good antifertility results with low failure rates relative to condoms. The present study showed the literature data that there is majority of plants, which are traditionally used as antifertility agents and their effects have not been thoroughly studied on animals. The majority of tests have been performed on conscious animals and relatively few tests have had their efficacy confirmed in humans. Herbal contraceptives are safer and cheaper methods for population overcoming. To summarize, a lot of the plant species listed here might appear promising as effective alternative oral fertility-regulating agents in males. Among plant parts, leaves have been maximally utilized for controlling fertility. As far as the relevance of the current review is discussed, it might be quite useful in generating monographs on plants and recommendations on their

Table $\mathbf{2}$ List of patents on a male contraceptive

\begin{tabular}{|c|c|c|}
\hline Summary of invention & Patent number & Inventor/assignee \\
\hline Substituted acylanilides and methods of use thereof & AU2015264895B2 & Dalton, James, Miller, Duane D. \\
\hline $\begin{array}{l}\text { Styrene maleic anhydride based formulation for male contraception } \\
\text { and prostate cancer }\end{array}$ & EP 2268290 B1 & Guha, Sujoy Kumar \\
\hline $\begin{array}{l}\text { Lonidamine analogs and their use in male contraception and cancer } \\
\text { treatment }\end{array}$ & EP 2502624 A1 & Chakrasali, Georg, Jakkaraj, Tash \\
\hline Orally active 7-alpha-alkyl androgens & EP1212345B1 & Louw Van Der, Leysen, Buma Bursi \\
\hline $\begin{array}{l}\text { Methods of making the 4-n-butylcyclohexanoic and the undecanoic } \\
\text { acid esters of ( } 7 \text { alpha, } 11 \text { beta)-dimethyl-17 beta-hydroxy-4-estren-3- } \\
\text { one and their medical use }\end{array}$ & EP1272196B1 & Blye, Kim \\
\hline $\begin{array}{l}\text { Oral pharmaceutical composition comprising 15-hydroxytestosterone } \\
\text { and its analogues }\end{array}$ & EP1551415B1 & Bunschoten, Coelingh Bennink, Van Der Linden \\
\hline Male contraceptive formulation comprising norethisterone & US20020103176A1 & $\begin{array}{l}\text { Eberhard Nieschlag, Axel Kamischke, Michael Oettel, } \\
\text { Alexander Ruebig, Ekkerhard Schillinger, Habenicht } \\
\text { Ursula-Friederike }\end{array}$ \\
\hline Male contraceptive method and composition & US20020164368A1 & Ronald Zimmerman \\
\hline $\begin{array}{l}\text { Androgen as a male contraceptive and non-contraceptive androgen } \\
\text { replacement }\end{array}$ & US20020193359A1 & Alfred J. Moo-Young \\
\hline $\begin{array}{l}\text { Reversible infertility in male mice following oral administration of } \\
\text { alkylated imino sugars: a non-hormonal approach to male } \\
\text { contraception }\end{array}$ & US20040019082A1 & $\begin{array}{l}\text { Aarnoud C. Van Der Spoel, Mylvaganam Jeyakumar, Terry } \\
\text { D. Butters, Raymond A. Dwek, Frances M. Platt }\end{array}$ \\
\hline Non-hormonal compositions and methods for male contraception & US20190290615A1 & $\begin{array}{l}\text { Guillaume Ei Glaoui, Mehdi Ei Glaoui, Philippe Perrin, } \\
\text { Stéphane Droupy, Véronique Agathon-Meriau }\end{array}$ \\
\hline Reversible male contraception & US4252798 & Donald J. Tindall \\
\hline Male contraceptive steroids and methods of use & US4297350 & John C. Babcock; J. Allan Campbell, Thomas J. Lobl, \\
\hline Oral male contraceptive & US4381298 & Patricia B. Coulson, Sheffield Dr. \\
\hline Male contraceptive implant & US5733565 & Alfred J. Moo-Young, Saleh I. Saleh \\
\hline Male contraceptives & US5854254 & Susan H. Benoff \\
\hline Buccal drug delivery system for use in male contraception & US6180682 & Virgil A. Place \\
\hline High-strength testosterone undecanoate compositions & US9480690 & $\begin{array}{l}\text { Chandrashekar Giliyar, Basawaraj Chickmath, Nachiannan } \\
\text { Chidambaram, Srinivansan Venkateshwaran }\end{array}$ \\
\hline Male contraceptive comprising a prolactin inhibitor and a sex steroid & W01999066935A1 & Lincoln, Kirkton Cottages, WU \\
\hline $\begin{array}{l}\text { A pulmonary drug delivery composition containing a progestogen } \\
\text { and androgen for use in a contraceptive method in males }\end{array}$ & WO2003068315A1 & Coelingh Bennink, Van Der Linden \\
\hline Novel spermicidal and anti-infective contraceptive device & WO2007074478A1 & Jain Rajesh, Jindal Kour Chand \\
\hline $\begin{array}{l}\text { Substituted (5,6)-dihydronaphraalenyl compounds as reversible male } \\
\text { contraceptives }\end{array}$ & WO2008137081A1 & Wolgemuth Debra J., Reczek Peter R. \\
\hline Inhibitors of eppin/semenogelin binding as male contraceptives & WO2009042565A2 & $\begin{array}{l}\text { O'rand Michael G., Widgren Esther Elaine, Richardson } \\
\text { Richard, Temple Brenda }\end{array}$ \\
\hline Non-hormonal male contraceptive agents and methods using same & WO2016205539A1 & Yan Wei \\
\hline Piperidine-dione derivatives for use as contraceptives & WO2018211276A1 & Sieng Bora, Lundvall, Steffi, Claudia Alejandra \\
\hline
\end{tabular}


use. Therefore, this review has highlighted the significant antifertility activity of herbal medicinal plants and their extracts. Moreover, this review can concentrate the interest of researchers on toxicity studies of phytoconstituents and their clinical trials, which may serve as an alternate potential antifertility agents with milder or fewer side effects and can be developed into suitable contraceptive formulations. Therefore, significant research into the chemical and biological properties of such lessexplored plants is still needed to determine their contraceptive efficacy and also will possibly define their toxic effects so that these ingredients can be utilized with confidence to regulate male fertility.

\section{Abbreviations}

LH: Luteinizing hormonesFSHFollicle-stimulating hormoneHDLHigh-density lipoproteinB.W.Body weight

\section{Acknowledgements}

Not applicable.

\section{Authors' contributions}

We declare that this work was done by the authors named in this article: SV conceived and designed the study. AY carried out the literature collection of the data and writing of the manuscript. AY and SV assisted in the data analysis and corrected the manuscript. The authors read and approved the final manuscript.

\section{Funding}

Not applicable.

\section{Availability of data and materials}

All the information in the manuscript has been referred from the included references and is available upon request from the corresponding author.

\section{Ethics approval and consent to participate}

Not applicable.

\section{Consent for publication}

Not applicable.

\section{Competing interests}

The authors declare that they have no competing interests.

Received: 3 August 2020 Accepted: 7 December 2020

Published online: 18 January 2021

\section{References}

1. Soni PK, Luhadia G, Sharma DK, Mali PC (2015) Antifertility activates of traditional medicinal plants in male with emphasis on their mode action: a review. J Glob Biosci 4:1165-1179

2. Kaur R, Sharma A, Kumar R, Kharb R (2011) Rising trends towards herbal contraceptives. J Nat Prod Plant Resour 1:5-12

3. Harisha B, Swamy VB (2012) Evaluation of antifertility activity of Melothria heterophylla (Lour.) Cogn. Res J Pharma Bio Chem Sci 3:754-771

4. India population web search, dated: 26 January, 2020 http:// worldpopulationreview.com/countries/india-population/

5. Singh R, Kakar S, Shah M, Jain R (2018) Some medicinal plants with antifertility potential: a current status. J Basic Clin Reprod Sci 7:7-19

6. Ghosh P, Gupta P, Tripathy A, Das B, Ghosh D (2018) Evaluation of hypotesticular activities of different solvent fractions of hydro-methanolic extract of the fruit of Terminalia chebula in Wistar strain adult albino rat: genomic and flow cytometric approaches. J Appl Biomed 16:394-400

7. Long JE, Lee MS, Blithe DL (2019) Male contraceptive development: update on novel hormonal and nonhormonal methods. Clin Chem 65:153-160

8. Amory JK (2016) Male contraception. Fertil Steril 106:1303-1309
9. Gupta RS, Sharma R (2006) A review on medicinal plants exhibiting antifertility activity in males. Nat Prod Rad 5:389-310

10. Michael GO, Silva EJ, Hamil KG (2016) Non-hormonal male contraception: a review and development of an Eppin based contraceptive. Pharmacol Ther 157:105-111

11. Afzalzadeh MR, Ahangarpour A, Amirzargar A, Varnamkhasti MK, Ganjalidarani H (2015) The effect of Vitis vinifera L. juice on serum levels of inhibin B, sperm count in adult male rats. World J Mens Health 33:109-116

12. Bhattacharya P, Saha A (2013) Evaluation of reversible contraceptive potential of Cordia dichotoma leaves extract. Rev Bras Farmacogn 23:342350

13. Tripathy B, Swain SN, Panda MK, Pradhan RN, Acharya UR (2018) Antispermatogenic effects of seed extract of Caesalpinia bonducella in Swiss mice. Int J Biosci 12:23-34

14. Zaman W, Ahmad M, Zafar M, Amina H, Ullah F, Bahadur S, Ayaz A, Saqib S, Begum N, Jahan S (2020) The quest for some novel antifertility herbals used as male contraceptives in district Shangla, Pakistan. Acta Ecol Sin 40:102112. https://doi.org/10.1016/j.chnaes.2019.05.017

15. Rajan TS, Sarathchandiran I, Kadalmani B (2013) Evaluation of newly developed herbal oral suspension for spermatotoxic activity on male Wistar albino rats. J Pharm Res 7:347-351

16. Sitasiwi AJ, Isdadiyanto S, Mardiati SM (2018) Effect of ethanolic Neem (Azadirachta indica) leaf extract as an herb contraceptive on Hepato-somatic Index of the male mice (Mus musculus). J Phys Conf Ser 1025:012043

17. Zaman W, Shah SN, Ullah F, Ayaz A, Ahmad M, Ali A (2019) Systematic approach to the correct identification of Asplenium dalhousiae (Aspleniaceae) with their medicinal uses. Microsc Res Tech 82:459-465

18. Khillare B, Shrivastav TG (2003) Spermicidal activity of Azadirachta indica (neem) leaf extract. Contraception 68:225-229

19. Singh N, Singh SK (2016) Citrus limon extract: possible inhibitory mechanisms affecting testicular functions and fertility in male mice. Syst Biol Reprod Med 62:39-48

20. Chakraborty K, Pal S, Bhattacharya AK (2003) Sperm immobilization activity of Allium sativum L. and other plants extracts. Asian J Androl 5:131-135

21. Sethi J, Yadav M, Sood S, Dahiya K, Singh V (2010) Effect of tulsi (Ocimum Sanctum Linn.) on sperm count and reproductive hormones in male albino rabbits. Int J Ayurveda Res 1:208-210

22. Petersen C, Söder O (2006) The sertoli cell-a hormonal target and 'super'nurse for germ cells that determines testicular size. Horm Res Paediatr 66:153-161

23. Burgess SA, Walker ML, Sakakibara H, Knight PJ, Oiwa K (2003) Dynein structure and power stroke. Nature 421:715-718

24. Nivsarkar M, Shrivastava N, Patel M, Padh H, Bapu C (2002) Sperm membrane modulation by Sapindus mukorossi during sperm maturation. Asian J Androl 92:233-235

25. Mandal TK, Das NS (2010) Testicular toxicity in cannabis extract treated mice: association with oxidative stress and role of antioxidant enzyme systems. Toxicol Ind Health 26:11-23

26. Sharma RS, Rajalakshmi M, Jeyaraj DA (2001) Current status of fertility control methods in India. J Biosci 26:391-305

27. Dufau ML, Winters CA, Hattori M, Aquilano D, Baranao JL, Nozu K, Baukal A, Catt KJ (1984) Hormonal regulation of androgen production by the Leydig cell. J Steroid Biochem 20:161-173

28. Sullivan R, Mieusset R (2016) The human epididymis: its function in sperm maturation. Hum Reprod Update 22:574-587

29. Jahan S, Rasool S, Khan MA, Ahmad M, Zafar M, Arsahd M, Abbasi AM (2009) Antifertility effects of ethanolic seed extract of Abrus precatorius $L$. on sperm production and DNA integrity in adult male mice. J Med Plant Res 3:809-814

30. Sofikitis N, Giotitsas N, Tsounapi P, Baltogiannis D, Giannakis D, Pardalidis N (2008) Hormonal regulation of spermatogenesis and spermiogenesis. J Steroid Biochem Mol Biol 109:323-330

31. Coutinho EM, Athayde C, Atta G, Gu ZP, Chen ZW, Sang GW, Emuveyan E, Adekunle AO, Mati J, Otubu J, Reidenberg MM (2000) Gossypol blood levels and inhibition of spermatogenesis in men taking gossypol as a contraceptive: a multicenter, international, dose-finding study. Contraception 61:61-67

32. Pakrashi A, Ray H, Pal BC, Mahato SB (1991) Sperm immobilizing effect of triterpene saponins from Acacia auriculiformis. Contraception 43:475-483

33. Chauhan A, Agarwal M (2008) Reversible changes in the antifertility induced by Aegle marmelos in male albino rats. Syst Biol Reprod Med 54:240-246 
34. Shyamlal YS, Jaiswal M, Prajapati PK (2012) Therapeutic potentials of Shirisha (Albizia lebbeck Benth)-a review. Int J Ayurvedic Med 2:153-163

35. Pankajakshy A, Madambath I (2009) Spermatotoxic effects of Cananga odorata (Lam): a comparison with gossypol. Fertil Steril 91:2243-2246

36. Souad K, Ali S, Mounir A, Mounir TM (2007) Spermicidal activity of extract from Cestrum parqui. Contraception 75:152-156

37. Kumar S, Biswas S, Mandal D, Roy HN, Chakraborty S, Kabir SN, Banerjee S, Mondal NB (2007) Chenopodium album seed extract: a potent spermimmobilizing agent both in vitro and in vivo. Contraception 75:71-78

38. Yakubu MT, Akanji MA, Oladiji AT (2007) Evaluation of antiandrogenic potentials of aqueous extract of Chromolaena odoratum (L.) KR leaves in male rats. Andrologia 39:235-243

39. Gupta RS, Yadav RK, Dixit VP, Dobhal MP (2001) Antifertility studies of Colebrookia oppositifolia leaf extract in male rats with special reference to testicular cell population dynamics. Fitoterapia 72:236-245

40. Shkukani HG, Salhab AS, Disi AM, Shomaf MS, Quadan FA (2008) Antifertility effect of ethanolic extract of Juniperus phoenica (L.) in male albino rats. J Herb Pharmacother 7:179-189

41. Rajasekaran M, Nair AG, Hellstrom WJ, Sikka SC (1993) Spermicidal activity of an antifungal saponin obtained from the tropical herb Mollugo pentaphylla. Contraception 47:401-412

42. Raji Y, Bolarinwa AF (1997) Antifertility activity of Quassia amara in male rats - in vivo study. Life Sci 61:1067-1074

43. Srivastav A, Chandra A, Singh M, Jamal F, Rastogi P, Rajendran SM, Bansode FW, Lakshmi V (2010) Inhibition of hyaluronidase activity of human and rat spermatozoa in vitro and antispermatogenic activity in rats in vivo by Terminalia chebula, a flavonoid rich plant. Reprod Toxicol 29:214-224

44. Gupta RS, Sharma A (2003) Antifertility effect of Tinospora cordifolia (Willd.) stem extract in male rats. Indian J Exp Biol 41:885-889

45. Dubey R, Dubey K, Sridhar C, Jayaveera KN (2011) Sperm immobilization activity of aqueous, methanolic and saponins extract of bark of Ziziphus Mauritiana. Der Pharm Sin 2:11-16

46. Singh A, Singh SK (2009) Evaluation of antifertility potential of Brahmi in male mouse. Contraception 79:71-79

47. Verma PK, Sharma A, Joshi SC, Gupta RS, Dixit VP (2005) Effect of isolated fractions of Barleria prionitis root methanolic extract on reproductive function of male rats: preliminary study. Fitoterapia 76:428-432

48. Sailani MR, Moeini H (2007) Effect of Ruta graveolens and Cannabis sativa alcoholic extract on spermatogenesis in the adult wistar male rats. Indian J Urol 23:257-260

49. Onyeka CA, Aligwekwe AU, Olawuyi TS, Nwakanma AA, Kalu EC, Oyeyemi AW (2012) Antifertility effects of ethanolic root bark extract of Chrysophyllum albidum in male albino rats. Int J Appl Res Nat Prod 5:12-17

50. Mali PC, Chaturvedi M, Ansari AS, Dixit VP (2001) Antispermatogenic effects of an ethanol extract of Citrullus colocynthis root in male albino rats. Pharm Biol 39:113-119

51. Vijaykumar B, Sangamma I, Sharanabasappa A, Patil SB (2004) Antispermatogenic and hormonal effects of Crotalaria juncea Linn. seed extracts in male mice. Asian J Androl 6:67-70

52. Muthu K, Krishnamoorthy P (2011) Antifertility activity of methanolic extract of Cuminum cyminumin seed on male albino rats. Int J Genet Eng Biotech 2:205-214

53. Mishra RK, Singh SK (2009) Reversible antifertility effect of aqueous rhizome extract of Curcuma longa L. in male laboratory mice. Contraception 79:479487

54. Yakubu MT, Akanji MA, Oladiji AT (2008) Effects of oral administration of aqueous extract of Fadogia agrestis (Schweinf. Ex Hiern) stem on some testicular function indices of male rats. J Ethnopharmacol 115:288-292

55. Jana TK, Das S, Ray A, Mandal D, Giri Jana S, Bhattacharya J (2013) Study of the effects of hibiscusrosa-sinensis flower extract on the spermatogenesis of male albino rats. J Physiol Pharmacol Adv 3:167-171

56. Gonzales GF, Ruiz A, Gonzales C, Villegas L, Cordova A (2001) Effect of Lepidium meyenii (maca) roots on spermatogenesis of male rats. Asian $J$ Androl 3:231-233

57. Bayala B, Telefo PB, Bassole IHN, Tamboura HH, Belemtougri RG, Sawadogo L, Malpaux B, Dacheux JL (2011) Anti-spermatogenic activity of Leptadenia hastata (Pers.) Decne leaf stems aqueous extracts in male wistar rats. $J$ Pharmacol Toxicol 6:391-399

58. Naseem MZ, Patil SR, Patil SR, Patil SB (1998) Antispermatogenic and androgenic activities of Momordica charantia (Karela) in albino rats. J Ethnopharmacol 61:9-16
59. Watcho P, Donfack MM, Zelefack F, Nguelefack TB, Wansi S, Nguola F, Kamtchouing P, Tsamo E, Kamanyi A (2005) Effects of the hexane extract of Mondia whitei on the reproductive organs of male rat. Afr J Tradit Complement Altern Med 2:302-311

60. Raji Y, Akinsomisoye OS, Salman TM (2005) Antispermatogenic activity of Morinda lucida extract in male rats. Asian J Androl 7:405-410

61. Etta HE, Bassey UP, Eneobong EE, Okon OB (2009) Anti-spermatogenic effects of ethanol extract of Mucuna urens. J Reprod Contracept 20:161-168

62. Obianime AW, Aprioku JS, Esomonu CT (2010) Antifertility effects of aqueous crude extract of Ocimum gratissimum L. leaves in male mice. J Med Plant Res 4:809-816

63. Gupta RS, Rehwani H, Khushalani V, Tanwar K, Joshi YC (2007) Antispermatogenic effects of Parkinsonia aculeata stem bark in male rats. Pharm Biol 45:1-8

64. Mishra RK, Singh SK (2009) Antispermatogenic and antifertility effects of fruits of Piper nigrum L. in mice. Indian J Exp Biol 47:706-714

65. Khouri NA, El-Akawi Z (2005) Antiandrogenic activity of Ruta graveolens $L$ in male Albino rats with emphasis on sexual and aggressive behavior. Neuroendocrinol Lett 26:823-829

66. Sharma A, Verma PK, Dixit VP (2003) Effect of Semecarpus anacardium fruits on reproductive function of male albino rats. Asian J Androl 5:121-124

67. Sharangouda JP, Satishagouda S, Vishwanatha T, Saraswati B (2010) Effect of terminalia bellirica barks extracts on activities of accessory reproductive ducts in male rats. Int J Pharm Sci Rev Res 1:75-79

68. Gupta R, Kachhawa JB, Gupta RS, Sharma AK, Sharma MC, Dobhal MP (2011) Phytochemical evaluation and antispermatogenic activity of Thevetia peruviana methanol extract in male albino rats. Hum Fertil 14:53-59

69. Aladakatti RH, Ahamed RN (2005) Changes in Sertoli cells of albino rats induced by Azadirachta indica A. Juss leaves. J Basic Clin Physiol Pharmacol 16:67-80

70. Gupta RS, Kachhawa JB, Sharma A (2008) Effect of methanolic extract of Dendrophthoe falcata stem on reproductive function of male albino rats. J Herb Pharmacother 7:1-3

71. Krishnamoorthy P, Vaithinathan S (2003) Effect of the extract of Thespesia populnea leaves on mice testis. J Environ Biol 24:327-330

72. Zi-Jian L, Zhi-Ping G, Rong-Fa L, Lin-Zhi Z (1992) Effects of multiglycosides of Tripterygium wilfordii (GTW) on rat fertility and Leydig and Sertoli cells. Contraception 45:249-261

73. Gupta RS, Dixit VP (1989) Testicular cell population dynamics following palmitine hydroxide treatment in male dogs. J Ethnopharmacol 25:151-157

74. Gupta RS, Sharma N, Dixit VP (1990) Calotropin-a novel compound for fertility control. Anc Sci Life 9:224-230

75. Oluyemi KA, Jimoh OR, Adesanya OA, Omotuyi IO, Josiah SJ, Oyesola TO (2007) Effects of crude ethanolic extract of Garcinia cambogia on the reproductive system of male wistar rats (Rattus novergicus). Afr J Biotechnol 6:1236-1238

76. Chakraborty S, Pakrashi A (1991) Antifertility effect of chronically administered Malviscus conzattii flower extract on fertility of male rats. Contraception 43:273-285

77. Mali PC, Ansari AS, Chaturvedi M (2002) Antifertility effect of chronically administered Martynia annua root extract on male rats. J Ethnopharmacol 82:61-67

78. Lohiya NK, Manivannan B, Goyal S, Ansari AS (2008) Sperm motility inhibitory effect of the benzene chromatographic fraction of the chloroform extract of the seeds of Carica papaya in langur monkey, Presbytis entellus entellus. Asian J Androl 10:298-206

79. Chaturvedi M (1995) Fertility regulation in male rats with the help of Echinops echinatus (Roxb) root extract. J Phytol Res 8:115-118

80. Coutinho EM, Melo JF, Barbosa I, Segal SJ (1984) Antispermatogenic action of gossypol in men. Fertil Steril 42:424-430

81. Saba AB, Oridupa OA, Oyeyemi MO, Osanyigbe OD (2009) Spermatozoa morphology and characteristics of male Wistar rats administered with ethanolic extract of Lagenaria Breviflora Roberts. Afr J Biotechnol 8:1170-1175

82. Olatunji-Bello II, ljiwole T, Awobajo FO (2009) Evaluation of the deleterious effects of aqueous fruit extract of Abelmoschus esculentus (okro fruit) on some male reproductive parameters in Spraque Dawley rats. J Phytol 1:461-468

83. Sinha R (1990) Post-testicular antifertility effects of Abrus precatorius seed extract in albino rats. J Ethnopharmacol 28:173-181

84. Yakubu MT, Afolayan AJ (2009) Reproductive toxicologic evaluations of Bulbine natalensis Baker stem extract in albino rats. Theriogenology 72:322332 
85. Ashok P, Meenakshi B (2004) Contraceptive effect of Curcuma longa (L.) in male albino rat. Asian J Androl 6:71-74

86. Takizawa T, Mitsumori K, Takagi H, Nasu M, Yasuhara K, Onodera H, Imai T, Hirose M (2004) Sequential analysis of testicular lesions and serum hormone levels in rats treated with a Psoralea corylifolia extract. Food Chem Toxicol 42:1-7

87. Melis MS (1999) Effects of chronic administration of Stevia rebaudiana on fertility in rats. J Ethnopharmacol 67:157-161

88. Mishra RK, Singh SK (2008) Safety assessment of Syzygium aromaticum flower bud (clove) extract with respect to testicular function in mice. Food Chem Toxicol 46:3333-3338

\section{Publisher's Note}

Springer Nature remains neutral with regard to jurisdictional claims in published maps and institutional affiliations.

\section{Submit your manuscript to a SpringerOpen ${ }^{\circ}$ journal and benefit from:}

- Convenient online submission

Rigorous peer review

- Open access: articles freely available online

High visibility within the field

- Retaining the copyright to your article

Submit your next manuscript at $\boldsymbol{\nabla}$ springeropen.com 